\title{
Determining Problems in Bilingual Public Information Signs
}

\author{
English Department, Faculty of Arts \\ Udayana University \\ Denpasar, Bali, Indonesia \\ ngurah_parthama@unud.ac.id \\ English Department, Faculty of Arts \\ Udayana University \\ Denpasar, Bali, Indonesia \\ alit_ida@yahoo.com \\ English Department, Faculty of Arts \\ Udayana University \\ Denpasar, Bali, Indonesia \\ tri_ediwan@hotmail.com
}

I Gusti Ngurah Parthama ${ }^{1}$, Ni Ketut Alit Ida Setianingsih ${ }^{2}$, and I Nyoman Tri Ediwan ${ }^{3}$

\begin{abstract}
This article aims in describing the bilingual public signs regarding to the product of two languages and the lexical choices. Bilingual public signs can be easily found in Bali for the reason of giving information to everybody. It is not only the Balinese or Indonesian people who can access the information, but also foreign people. Especially in relation to Bali as tourist destination, the bilingual public signs have great role in providing information. The data was taken from the bilingual public signs in Denpasar and Badung. Both are recognized as the capital city of Bali and the main tourist destination in Bali. Method of collecting data applied documentation and method of analyzing data was descriptive qualitative. It was described based on descriptive way qualitatively regarding to the theory of translation. The results show that two important things must be considered in bilingual public signs. First, the modes of literal and adaptation only result in problem of understanding the sign in TL. While in SL, the sign determines clear meaning. It comes from the structure of SL that is directly transferred to the structure of TL. Second, lexical choices also lead to new problem of interpretation. Correct lexical choices reflect naturalness of language based on the culture of foreign readers. They can find the meaning naturally. However, incorrect lexical choices only show confusion in understanding the meaning.
\end{abstract}

Keywords: public signs, bilingual, mode of translation, lexical choices

\section{INTRODUCTION}

In our society, one of media for communication is public information signs. Those signs consist of information or announcement for public and it is placed in public areas. The aim, of course, is to give information to the public about certain conditions, events, or others. As the mode of communication, public information signs are not only read by certain group of people, but they are also read by other foreign people with different background languages. This especially occurs in Bali as the main tourist destination in Indonesia. The signs are also read by tourists.

In Bali, it is common to find bilingual public information signs. Those bilingual signs can be seen in some tourist destinations. The reason is Bali is well-known for its international community, especially with those who are visiting Bali to enjoy its beautiful places, panorama, or the culture of Bali. The public signs present the information in two languages, Indonesian and English. The use of English represents the international lingua franca that can be understood well by most of foreign people. With those bilinguals model, then it is not only Indonesian people know the information, but also foreign people can be informed by the public signs.

The challenge in its use of bilingual is to transfer the meaning of language. The Indonesian and the English information are placed at once. It is side-to-side. However, the English version is sometimes awkward. It sounds weird to understand the English version. It means there is a problem in process of translating the SL. We have to realize that Indonesian and English have different structures. It represents the unique of certain language. The process of translation is actually not merely changing the form by taking the source language (SL) to the target language (TL). But, in the process of translation there is a consideration for 
meaning. The focus is the meaning, while the form is suited to the structure of TL. In Bali, several bilingual public information signs have problem in their English. Meanwhile, there must be one on one translation used in translating the Indonesian into English. Consequently, the meaning of the SL is different in English. It should be aware that the understanding of foreign people is different. If their understanding is different, then the core meaning of the information could not be delivered. It also causes misunderstanding among them.

Parthama (2006) in its thesis entitled The Translation of Balinese Religious Terms describes the effort to maintain meaning in translating religious cultural terms of Hinduism to English language. It is, of course, similar to the general process of translation. The concept of translation is actually translating one language that is close to certain group of people to different languages. The languages are used by other different group of people. The focus of this writing is there is special specification to the Balinese religious terms. It is a challenge for translator to translate Balinese religious terms. Transferring the meaning of specific terms requires certain procedures. The procedure enables the meaning of SL to be transferred to the TL. The correct procedure gives the same impact of meaning to the readers of TL. In this writing, the procedure of calque and literal are mostly used in translating the Balinese religious terms.

The model of translating specific terms in Balinese is also written by Setianingsih (2003). She describes the importance of maintaining meaning in translating Balinese cultural terms. In her writing entitled Some Alternative Ways of Establishing Lexical Equivalences of Balinese Cultural Terms in English, she concludes that there are many ways to use in achieving the goal of idiomatic translation. The idiomatic translation requires the possible same meaning of SL and TL. At the same time, the readers of TL recognize the understanding of meaning of the terms. Her writing used the data of Balinese cultural terms that were taken from the book of Bali Art Festival. She found that there are some alternative ways in transferring the meaning of the cultural terms from Balinese to English. The alternative ways reflect the effort to have idiomatic translation. It is mentioned that the application of alternative ways is to give opportunity for the readers of TL to understand the cultural terms. It gives clear understanding about specific terms. In her writing, the common ways to translate Balinese cultural terms is the application of descriptive phrase.

The focus of result in translating specific information is also written by Parthama (2016). His research report entitled Kesalahan Penggunaan Bahasa Inggris di Masyarakat: Kajian Sosiogramatika (The Mistakes of Using English in Society: Socio grammatical study) describes that the use of English in public information signs is wrong. The mistakes cause misinterpretation for the foreign readers. The misinterpretation of foreign readers is reasonable since they have the background of English. Meanwhile, the English in public information signs are only translated literally from the Indonesian as the SL. At the same time, it must be considered that the two have different characteristics and structures. People who use it in communication are also different. As the result of literal translation, the English sounds weird or awkward. It leads to different interpretation. The research also gives description about the common mistakes are the choice of vocabularies and structure. For example, the direction of traffic light belok kiri jalan terus as SL and various translations of English language. As conclusion, the use of English is not resulted from the translation, but it must be the English in the mode of informative. Since it is used in public signs, the English should not merely be translated from Indonesian.

Beeckman and Callow (in Larson, 1998: 173) propose three concepts in transferring meaning if there is no lexical equivalent between the languages. The concept is commonly used in translation procedure. Those concepts are as follows;

1. The source language (SL) uses general terms; however, the target language (TL) uses specific terms in its semantic meaning.

2. The SL uses specific terms; meanwhile the TL only has general terms in its semantic meaning.

3. In the process of transferring meaning, the SL should be interpreted in general understanding, but it is interpreted specifically in TL.

Those three concepts are commonly found in process of transferring meaning. The only reason is the uniqueness of languages in the world. There is no typical same feature of language. There is always specific condition for the language used by certain group of people. This condition comes from the understanding of language as part of culture. While, culture reflects certain condition of people that they are inherited the values, customs, traditional, and others from generation to generation.

Solving the three problems above, Beeckman and Callow (in Larson, 1998: 179) prefer using procedures in translating process. The procedures are namely;

1. Procedure of applying general with descriptive phrase or specific description.

2. Procedure of applying loan word.

3. Procedure of applying a cultural substitution.

\section{RESEARCH METHOD}

The data source was taken from public information signs in Denpasar and Badung. The public information signs consist of announcement, notification, prohibition, and other important signs for public. The area of Denpasar and Badung were chosen for different reason. Denpasar is the capital city of Bali, while Badung has some famous tourist destinations in Bali. For this reason, it is believe that those regencies have applied the bilingual public information signs. Especially, when there is a relation with the tourism.

The method of collecting data was documentation method. The observation was applied in relation to some techniques in collecting data. The earlier technique was documentation by taking picture of all the public information signs. Then there was technique of selection in order to select the appropriate data. After that, the 
techniques of reading in detail and taking note were applied. These two techniques were used to prepare the chosen data.

The method of analyzing data was descriptive qualitative. The chosen data was classified for the types of mode of transferring meaning. In this process, the classification data was the main process in this research. The technique of descriptive qualitatively was applied in describing the data that was supported by qualitative analysis of transferring meaning. In this case, the SL and TL were placed in table to recognize the relation between the two languages and analyze it descriptively.

\section{RESULT AND DISCUSSION}

There are three public information signs that are analyzed in this article. Each represents certain public areas and those are composed in bilingual. Each of data is described for content of signs, the process of transferring meaning, and finally, the appropriateness of the bilingual signs regarding to the meaning.

The following first data is bilingual public sign. It is placed in the area of hospital. The SL sign is kawasan bebas asap rokok and the TL is please refreain from smoking. This is the model of sign in giving notification or announcement about not having smoking in certain area.

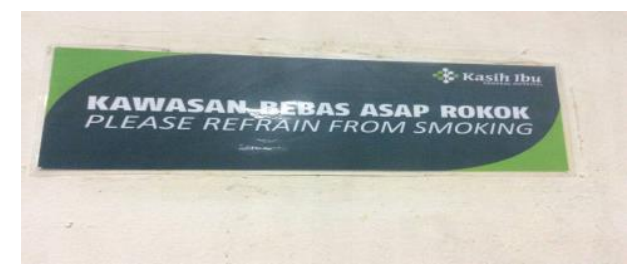

The data above uses procedure of adaptation in transferring meaning. SL expression kawasan bebas asap rokok is translated with adaptation to TL expression please refrain from smoking. The adaptation shows there is the basic meaning of sameness in SL and TL. The use kawasan bebas asap rokok means people are not allowing to smoke in the area. This strong notification is represented in TL by the expression of please refrain from smoking. The basic sameness meaning is somebody does not allow smoking in the area. In TL, it represents by the use of refrain.

Descriptively, the SL has strong meaning in its notification. It is supposed not to smoke in the area of hospital. Meanwhile, in TL the meaning is weak. It only gives sign of please refrain from smoking. The strong meaning of SL does not occur in TL. The use of phrase please refrain from smoking tries to emphasize the word refrain. In general, the word refrain means somebody should stop doing something, especially when somebody wants to do.

The use of refrain actually represents the inner prohibition for not doing something. This actual means in TL does not correspond in SL. In SL, the use kawasan bebas asap rokok reflects the outer prohibition for not smoking. This means there is regulation must be concerned by other people in the area. However, the use of please refrain from smoking only requires someone to stop doing something from his/her desire.

One thing should be realized in giving information to the public bilingually, we have to realize the culture of English language. English allows clear understanding of language. In this sign, there should be clear sign that has the same impact in SL as well as TL. When, there is strong prohibition in kawasan bebas asap rokok, then the TL also represents the same thing. There is alternative mode of phrase like do not smoking here. The phrase do not smoking here reflects strong prohibition and it has the same impact with SL.

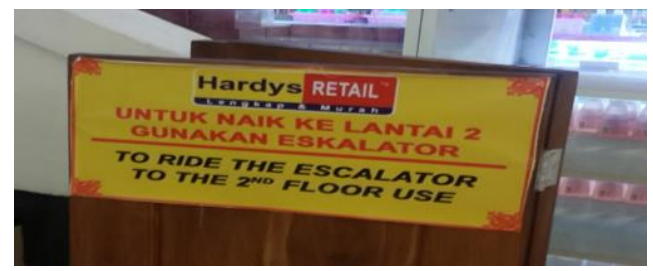

The second data is the mode of announcement. The sign is kind of giving a direction in one of shopping malls in Denpasar. The SL expression is untuk naik ke lantai 2 gunakan eskalator and the TL expression is to ride the escalator to the $2^{\text {nd }}$ floor use. This bilingual sign applies the model of literal translation. The literal refers to the structure of SL in giving information of TL. It is the reason that the sign in TL sounds awkward and rigid. Because the sign uses the structure of SL or Indonesian language.

The mode of literal in transferring meaning also requires one-to-one word translation. It means that each word in SL is translated literally into TL. The following diagram shows the literal between the SL and TL.

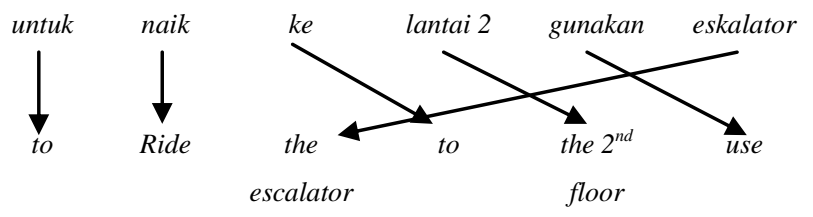

The arrow shows the relation of SL and TL words. In the diagram, all of the words in SL is translated into TL. For example, the word untuk in SL is translated into to in $\mathrm{TL}$ and the word naik into ride. Others, only small variation of arrows is applied to show literal mode of transferring meaning from SL and TL.

Besides its awkward and rigid form, this English sign also sounds strange for lexical choices. It can be seen from the use of ride. The word ride has relation to sit on a horse and control its move. However, the use of escalator does not relate with ride. The structure and lexical choices results in problem of understanding the meaning of announcement.

There is an alternative way to give sign in English rather than using literal mode. Transferring meaning especially in sign does not always result in good understanding. In SL, the use of untuk naik ke lantai 2 gunakan eskalator is a direction and it has understandable meaning. In alternative way, the English version can be use escalator to the $2^{\text {nd }}$ 
floor or to the $2^{\text {nd }}$ floor, use escalator. This alternative expression in TL proposes two different points of view. The expression use escalator to the $2^{\text {nd }}$ floor emphasizes to the media or tool to other floor. While, the expression to the $2^{\text {nd }}$ floor, use escalator focuses to the moving of different floor. The use of both alternatives is based on the importance of the sign.

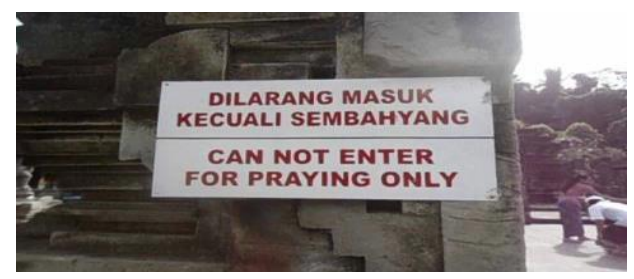

The third data above also shows prohibition. It was taken from the area of holy place or temple of Hindu. The SL expression shows dilarang masuk kecuali sembahyang and the TL shows sign of cannot enter for praying only. This bilingual public information sign applies the mode of literal in transferring meaning.

The literal mode can be seen from one-to-one translation of SL into TL. For example, dilarang in SL is translated into can not in TL. Meanwhile SL masuk is translated into TL enter. Variation only comes from the phrase in SL kecuali sembahyang that is translated into for praying only in TL.

The use of modality can in can not enter in TL has no equal strong prohibition. It is supposed to have another option in prohibiting others to enter the temple. The SL dilarang masuk kecuali sembahyang can be alternatively transferred into do not enter for praying only. The use of $d o$ not refers strong prohibition and it is common used for sign of prohibiting. For example, do not enter private area or do not enter, under construction. The use of do not here has significant impact to the reader in interpreting the meaning of prohibition.

\section{CONCLUSION}

The analysis of bilingual public information signs results in two conclusions. First, the mode of transferring meaning focuses on literal and adaptation. The literal concerns mostly on one-to-one translation, while adaptation tries to adapt the information in SL into TL structure. It does not work appropriately since the SL of Indonesian and TL of English do not have similar structure. The unique of structure of a language cannot be transferred directly to different languages since it causes strange result. Second, lexical choices turn to be a problem in English. Correct lexical choices show the naturalness of language. Naturalness directs the readers to get the idea and understand the meaning of the sign. However, the incorrect lexical choices only lead to confusion of interpreting the sign.

\section{REFERENCES}

[1] Larson, Mildred L. 1998. Meaning-Based Translation, A Guide to Cross-Language Equivalence. Oxford: University Press of America.
[2] Mahsun, M.S., Prof. Dr. 2005. Metode Penelitian Bahasa, Tahapan strategi, metode, dan tekniknya. Jakarta: PT RajaGrafindo Persada.

[3] Molina, L dan Albir, A.H. 2002. "Translation Technique Revisited: A Dynamic and Functionalist Approach". Dalam Meta, Vol. XLVII, No. 4. Hal. 499 - 512. http://www.erudit.org

[4] Parthama, I Gusti Ngurah. 2006. "The Translation of Balinese Religious Terms". (Tesis). Denpasar: Program Studi Linguistik, Program Pascasarjana, Universitas Udayana.

[5] Parthama, I Gusti Ngurah. 2016. Kesalahan Penggunaan Bahasa Inggris di Masyarakat: Kajian Sosiogramatika. Laporan Penelitian Hibah Unggulan Program Studi (HUPS) Lembaga Penelitian dan Pengabdian kepada Masyarakat (LPPM) Universitas Udayana.

[6] Setianingsih, Alit Ida. 2003. "Some Alternative Ways of Establishing Lexical Equivalences of Balinese Cultural Terms in English. (Tesis). Denpasar: Program Studi Linguistik, Program Pascasarjana, Universitas Udayana. 